\title{
THE INJUNCTION AS A REMEDY FOR THE BOYCOTT.
}

A boycott is a system of social and business ostracism. It signifies, in a general way, a combination of many to withdraw from an individual their own beneficial intercourse, and the intercourse of all others whom they can influence. If this is accomplished by an exercise of the lawful rights of the combination, without a violation of the corresponding rights of the individual, it is legal, although it results in his financial and commercial ruin. Illustrations of this are of frequent occurrence in the commercial world, and are regarded simply as competitive acts in the ordinary course of trade. 1 The right of an individual or corporation to refuse to employ men who trade with, or are tenants of, persons objectionable to them also illustrates this legal system of boycotting. ${ }^{2}$ If, however, this ostracism is accomplished by unlawful means, such as forcing outsiders by threats or intimidations against their will to withdraw their beneficial intercourse, the entire legal complexion of the combination changes. Characterized by unlawful acts it savors of conspiracy, which is held to be a combination of two or more persons to do an illegal act, and all those aiding or abetting are fellow conspirators. No overt act is necessary to make them amenable to the common law. ${ }^{3}$ The mere conspiring to coerce unlawfully is the gist of the crime. The combination now becomes a criminal boycott, which is more concisely defined as a conspiracy to injure or ruin an individual by directly or indirectly preventing his carrying on any business, and by unlawfully coercing others to withdraw from him their beneficial intercourse through threats that unless they do so they will also suffer injury. $4^{-}$

The criminal boycott is the recognized weapon of labor unions, and is used by them with unremitting vigor and frequently with

1 Mogul Steamship Co. v. McGregor, 23 L. R. Q. B. D. 598.

2 Payne $v$. Western, etc., R. R. Co., I3 Lea 507; Heywood v. Tillson, 75 Me. 225 .

3 State $\%$. Glidden, 55 Ct. 46.

4 See Anderson's and Black's Law Dictionaries. 
great success, to secure from their employers acquiescence to their numerous and varied demands. In most cases it is introduced by, and used conjointly with, a strike. Strikes which consist in a simple withdrawal of the employés are legal, except when they sever contractual relations, or endanger life or property ${ }^{5}$ but in most fields of industry they are ineffective in securing the desired concessions because of the large supply of laborers ready to take the strikers' places, preventing thereby any serious delay or financial loss to a business. It is then that the boycott is applied with terrible effectiveness by driving out the employés remaining at work, through coercion, intimidation or violence, by forcibly restraining those who would take the strikers' places, and by preventing through intimidation the employer's regular line of customers, and even the public at large, from dealing with him. The sole purpose of the boycott is to break or ruin the employer through an annihilation of his business by severing all his relations, mercantile and industrial, contractual and voluntary, and thus to deprive him of even the means of sustenance. It is an organized system of coercion or revenge, opposed to the public weal and subversive of our fundamental principles of government.

The law is not opposed to combinations for good, but favors and protects them. Both in England and this country labor unions, having for their object the advancement of the moral, social and intellectual development of their members, the securing of fair compensation with reasonable hours and conditions of labor, and the raising of funds for the care of their sick, disabled or unemployed members, are encouraged and chartered by law. ${ }^{6}$ But it does not favor or permit such organizations to invade the rights of others by coercing men against their will to join them, or to force men out of employment who are satisfied with their remuneration, or in any unlawful manner to interfere with an employer in the management of his business. Both employer and employe have a constitutional right to use their capital, labor or skill as they please, without restraint from outside parties, and any attempt by force, threat or intimidation to control an employer in his method of conducting his business, or to dictate whom he shall or shall not employ, or what wages he shall pay; or any interference with an employé by forcing him into a labor organization, or compelling him to quit work, or in any direct or

538 and 39 Victoria, chap. 86, I 875

622 Vict., c. $34 ; 3^{2}$ and 33 Vict., c. $6 \mathrm{I} ; 34$ and 35 Vict., c. $3 \mathrm{I} ; 24$ Stat., c. 567 . 
indirect manner attempting to control his freedom of action, is illegal and will not be tolerated. The entire system, opposed to the peace, prosperity and civilization of our country, well merits the condemnation placed on it by the grand jury of the Theiss boycott, " who referred to it in their indictment as "an accursed exotic," and "a hydra-headed monster dragging its loathsome length across the continent and sucking the very life-blood from our trade and commerce."

The remedies afforded by courts of law for this pernicious system are two, - a criminal action, resulting in case of conviction in fine or imprisonment, and a civil action for damages to the injured party. In equity, however, an injunction will be granted to prevent the further continuance of an existing wrong or the commission of a threatened wrong. There is a strong tendency, especially noticeable in the last few years, to seek relief from a boycott through a court of equity rather than through a court of law. This is due to the marked difference in the relief afforded by each of the courts, arising from their different modes of procedure. The common law theory is, that a man must not be interfered with until he has committed a wrong, while the equity theory is that the ideal remedy is one which precludes the commission of a wrong, rather than that which awards punishment or satisfaction for a wrong after it is committed. Acting on this theory, the common law does not attempt to prevent the commission of a wrong directly, but contents itself with threatening a would-be transgressor with a fine or imprisonment if he commits a public wrong, and with the payment of such damages to an injured party as will restore him to his original position, if he commits a private wrong. When no overt act has been committed in a conspiracy, there is often great difficulty in securing evidence necessary for conviction, and even when procurable, the invisible bond of sympathy which too frequently exists between a jury and the indicted conspirators causes a verdict to be rendered with a plea for clemency. The payment of fines to the State or the imprisonment of wrongdoers are punishments for the general wrong done the public, but in no sense do they compensate for the special wrong done the individual. Compensation for the individual is secured only by a civil suit, but if the theory that a pecuniary compensation cures all private wrongs were correct, which it is not, it is obvious that a practical application of it would and does fail in many cases. Some injuries are of an irreparable nature and cannot be measured by a pecuniary standard, or if

7 People $v$. Wilzig, 4 N. X. Crim. Rep. 403. 
capable of such measurement, the insolvency of the wrongdoer precludes the restoration of the injured party.

Equity, however, acting on the broader theory that justice requires that no wrong be done, has processes especially adapted to secure these ends, the most powerful of which is the writ of injunction. This is a restraining order, issued by the court on application of a complainant with suitable affidavits, commanding those on whom it is served to refrain from doing, and in rare cases to do, certain acts. Once served, it prevents the commission of threatened wrongs, or causes the cessation of continuing wrongs, by placing in contempt of court all those who disobey the command. It is the most powerful process issuing out of either a law or equity court, and is sometimes referred to as the strong arm of the law, and is applied with great caution. It is issued only when the rights of the respective parties are certain, and not for the prevention of naked trespasses or criminal acts unconnected with property rights. There must be a strong probability of positive, substantial and irreparable injury to warrant the court's interference, and not mere irregular and unauthorized acts which have no injurious consequences. Both in England and this country the granting of injunctions is largely in the discretion of the court, and jurisdiction is never assumed where there is a plain, adequate and complete remedy to be had in a court of law. A few recent cases will show the grounds upon which courts will issue this writ, and its adaptability to fit varied circumstances and prevent the commission of a class of wrongs of a continuing nature which cannot be redressed, or only inadequately redressed, in a court of law.

With great unanimity the courts of both countries hold that acts which tend to misrepresent a business, to its injury and that of the proprietor, are mere libels and will not be restrained; 8 but where the attempt to injure consists of acts or words tending to intimidate and prevent customers from dealing with, or laborers from working for, a party, an injunction will lie.

In Springhead Spinning Co. $v$. Riley, ${ }^{9}$ striking spinners placarded the town and published in the papers a request that all sympathizers with their union avoid the company's office until the settlement of the trade dispute. The Court held that there.was sufficient ground for an injunction, as the scheme was by intimidation to prevent persons accepting work from the plaintiff and as a consequence to destroy his business.

8 Cent. Law Journal, Vol. 35, 4r5; Francis v. Flinn, II8 U. S. 385 ; Kidd v. Horry, 28 Fed. Rep. 774; Clark $v$. Freeman, II Beav. II2.

9 L. R. 6 Eq. 55 I. 
This decision was supported in Sherry $v$. Perkins, ${ }^{10}$ where strikers in complainant's shop were restrained from marching back and forth before it with banners, requesting all workmen to. keep away, and by their number intimidating those who wished to work.

In Casey $v$. Cincinnati Typo-Union, ${ }^{11}$ an injunction was maintained to prevent members of a labor union from circulating hand-bills and making personal calls, in which they requested the news dealers to cease handling the papers of the complainant, the advertisers to withdraw their "ads," and the public generally to withdraw their patronage, accompanied by implied threats of injury if they failed to comply.

In Murdock, Kerr \& Co. v. Walker, ${ }^{12}$ an injunction was issued to restrain members of a union from forcibly preventing the shipping of a crew, as the acts were in restraint of trade, and " for the reason that damages at law for interrupting the business, and intercepting the profits of pending enterprises and voyages, must in their nature be conjectural and not susceptible of proof."

Unlawful interference with a business by picketing the works and forcibly escorting laborers filling strikers' places out of the State, has been restrained. The Court held that the avoidance of a multiplicity of suits, and the fact that the defendants were insolvent, were "both prime reasons that appealed to a court of equity for its preventive relief."13

The scope, power and economic advantages of this remedy are forcibly shown in the cases of the Toledo, etc., R. R. Co. v. Penn. Co. et al., ${ }^{14}$ where a labor organization composed of engineers declared a boycott against the plaintiff's road, and by intimidation compelled all connecting roads to assist them by refusing to exchange freight cars with the boycotted road. The effect of such a boycott would have been the tying up of the railroad, the cutting off from the rest of the country of the entire territory through which its tracks lay as arteries of trade, the suspension of manufactories and business houses along its line, and the infliction of great inconvenience and suffering on many thousands of citizens within and without that territory, wholly innocent of the cause of the trouble. At the prayer of the complainant, a mandatory injunction was issued, compelling the chief of the labor organization to recall

10 I47 Mass. $2 \times 2$.

1145 Fed. Rep. I35.

12 I52 Pa. 595 .

13 Hagan $v$. Blindell, 54- Fed. Rep. 40.

14 Toledo A. A. \& N. M. R. R. Co. v. Pa. Co., 54 Fed. Rep. 730 , also 746. 
his order commanding the engineers on defendant roads to quit work for the purpose of coercing them into a refusal to handle the cars, such a refusal being a violation of the interstate commerce laws; and another mandatory injunction was granted, compelling the defendant roads to handle the cars, on the grounds that "the case was urgent, the rights of the parties free from reasonable doubt, and the duty sought to be enforced was imposed by law."

An injunction of even greater breadth than any of the preceding, which penetrates to the very root of strikes and boycotts, and because of its scope, has brought the whole subject of injunctions under a present special investigation by the Judiciary Committee of the United States Senate, is that issued by Judge Jenkins of the Circuit Court, restraining the executive officers of the various organizations of railway employés "from ordering, recommending, advising or approving by communication, or instruction or otherwise, the employes * * * of the Northern Pacific Railroad Company *** to join in a strike on January I, I894, or at any other time, until further order of this court," and restraining the employés themselves "from so quitting the services of the said receivers [of the Northern Pac. Railroad] with or without notice, as to cripple the property, or to prevent or hinder the operation of said road." Such an order, at first reading, appears to enslave the employés and deprive them of their unquestioned right to work when, and for whom, they please, but the Court, distinctly acknowledging that right, held that it was a relative and not an absolute right. Prior to entering service it was undoubtedly absolute, but the moment the relation of employer and employe was established it became relative, and the employés possessed no legal right to quit premeditatedly the service of the road at such a time and in such a manner as to injure it. A lawful condition precedent to the exercise of their right of withdrawal, was the giving of such reasonable notice as would prevent the crippling of the road and the mail, telegraph and express facilities afforded by it to the public. 15

So frequent have become the outbreaks in the industrial world between the representatives of capital and labor, and so severe and far-reaching are the injuries inflicted by the latter, that the demand for relief through a writ of injunction is constantly increasing, and no branch of the law is in a more rapid state of development, but while the principles governing its issue are sim803.

15 Farmer's Loan \& Trust Co. v. Northern Pac. R. R. Co., 6o Fed. Rep. 
ple, it frequently taxes the judgment of our most learned judges to apply them. The cases summarized show a willingness of courts of equity to assume jurisdiction and issue injunctions when irreparable injury can thereby be avoided, when it is apparent that a pecuniary compensation will be inadequate, when the parties are insolvent and cannot respond in damages, and when a multiplicity of suits can be avoided.

From the inherent nature of an injunction, it is especially suited to give relief from the threatened injuries of a boycott. It is easily and quickly secured, it is promptly and effectively served, it is preventive as well as remedial, it gives immediate and positive relief, it is binding on all within or without the jurisdiction of the court, it maintains the relative positions of the parties with justice to each, it may be moulded to the peculiar circumstances of each case, it may be dissolved, revived, continued, extended or contracted, it may be special, preliminary, temporary or perpetual; in short, it is especially adapted to prevent the commission of wrongs and preserve the rights of all parties. 